pushed these researches to such successful issues belongs chiefly to the chemists, mineralogists, and geologists of France. To the labours of Senarmont, Daubrée, and a host of other workers, we owe the artificial production of a very large number of the minerals of our globe; while the ingenious experiments of Fouqué and Michel Lévy have resulted in the formation of many rocks differing in no essential particulars from those which have been produced by natural agencies.

In the prosecution of his various researches the importance and value of exact mineralogical knowledge to the geologist is becoming every day more apparent. The temporary estrangement between the cultivators of mineralogy and geology is now, we may hope, for ever at an end ; very heartily, indeed, do geologists recognise and welcome the aid of their brethren the mineralogists.

But if it be confessed that the benefits, past and prospective, conferred on geological science by mineralogy are vast and even incalculable, it must also be admitted that the debt is amply repaid by the beneficial influence which is being exercised in turn upon mineralogy by geology.

Some time ago a distinguished mineralogist asked me if I did not find the ordinary text-books of his science but little calculated to arouse the interest or excite the enthusiasm of students. I am sure that the energy of my assent must at least have assured my friend of the strength of my convictions on the subject.

Too long, indeed, has the accumulated mass of mineral lore recalled the grim vision of the seer of Chebar. In that gruesome valley the wail of the student, "the bones are very dry," has mingled with the sigh of the teacher, "Can these bones live?" But now from the four winds of heaven come the constructive ideas of many mindsfrom Scandinavia and from France, from Germany and from the United States - and in obedience to this influence behold "a great shaking" in the formless mass. Scattered facts, isolated observations, imperfect generalisations, and tentative hypotheses are falling together "bone to his bone," and are building up a sound body of mineralogical knowledge; and into this the spirit of geological thought entering, mineralogy shall stand forth a living science.

\section{DR. WILLIAM TRAILL, OF WOODWICK ${ }^{1}$}

THE death of this assiduous student of natural history merits more than a passing notice, since there are few surgeons who did more for the advancement of Eastern conchology than he; while his researches on the antiquities of his native county (Orkney) also claim attention. His whole career, indeed, as in the case of many an Eastern surgeon, illustrutes the wisdom of placing both natural history and botany on the curriculum of every medical student.

Dr. Traill was the eldest son of Mr. Traill, of Westness, Rousay, Orkney, and he was born in Kirkwall on September 8, I818. He proceeded to the University of Edinburgh to study medicine at the age of sixteen, and while there he had the advantage of the direction and advice of his uncle, the late Prof. Traill, who held the Chair of Medical Jurisprudence. Young Traill proved an apt student, and showed from the first a strong liking for natural history. This was fostered by his uncle (whose collection of snakes, now in the Museum of Science and Art, was well known to naturalists), as well as by his pursuits during the holidays at the family seat at Westness, in the Island of Rousay. Amongst his fellow-students were Dr. Cleghorn, of Stranthie, late Conservator of Forests in India, Sir Lyon Playfair, and Dr. Halliday Douglas.

After graduating in $184 \mathrm{I}$, he proceeded to India as a surgeon in the East India Company's service. The I Abstract of Paper read at the Literary and Philos phical Society, St.
Andrews, January $2 \mathrm{r}, \mathrm{r} 887$. splendid field thus opened up to the young naturalist stirred all his energies into activity, and he studied and collected various groups, but especially the land-shells of Madras. His early studies on the shores of Orkney had given him a predilection for this department, and he remained faithful to it throughout life. Thus, when shortly afterwards called to serve in China, he began the collection of those beautiful specimens of Eastern shells now so well known in many collections. His opportunities were further extended by a residence of some years at Singapore, and afterwards at Malacca and other stations. He returned to England in 1854 , and his collections were much admired, both as regards the beauty of the specimens and the number of examples of each species. His acquaintance with Dr. Knapp, a retired army surgeon, and also well known as a malacologist, gave a great impetus to his studies, as also did his association with Andrew Murray, Robert Gray, Dr. Howden, Wyville Thomson, Foster Heddle, James Cunningham, Patrick Dalnahoy, and R. Greville.

His return-voyage to India in 1856 gave him an opportunity of examining the pteropods and other pelagic mollusks, and his observations, with four plates and a chart, were communicated by Sir Walter Elliott to the Madras Fournal, then edited by his friend Dr. Cleghorn. His preparations of the delicate glassy shells of the Thecosomatous forms was remarkable. He also described some rare species, observed certain peculiarities in their structure, and made comparisons between the velum of the young Cyprea and the epipodia of the pteropods. If is collection of Eastern mollusks was largely increased during his second period of duty, so that it became celebrated for certain rare types, such as Rostellaria rectirostris, Trochus guilfordit, Trochus imperialis, \&c. He also added largely to Prof. 'Traill's collection of snakes formerly alluded to.

On retiring from active duty he settled at St. Andrews, and at once took an active interest in the University Museum and Literary and Philosophical Society, of which latter he was a Vice-President at his death. He spent much of his time in arranging the Mollusca in the Museum, and he enriched the collection by many interesting and rare types. In his annual trips to his estate in Orkney he also made researches on the antiquities and geology of the district, and these he embodied in papers communicated to the Edinburgh Antiquarian Society, and to the Society at St. Andrews. Amongst these papers are the following :- "Results of Excavations at the Broch of Burrian, Orkney," two plates and woodcuts; "Notice of Excavations at Stenabeck, Orkney," with woodcuts; "On Submarine Forests in Orkney" ; On the Picts" Houses of Skerra Broc"; "On the Recurrence of Boulder-Clay in Orkney"; "Notice of the Boulders in North Ronaldshay," \&c.

His knowledge of botany also enabled him to acclimatise various plants in Orkney, such as Phormium tenax, various Veronicas, the Manuka (Capt. Cook's sea-plant), the Japanese Euonymus, and others.

Dr. Traill was a man of refined and cultivated mind, genial but unobtrusive, and had a large circle of friends. He enjoyed good health till eighteen months ago, when the first symptoms of the disease which ultimately proved fatal appeared.

W. C. M.

\section{THE EARTHQUAKE}

A SERIES of shocks of earthquake has caused much A havoc in the Riviera during the last week. Although it is too early to attempt to give a complete account of what has happened, the leading facts, so far as they are of scientific interest, are well summed up in the following report, issued by Father Denza, of the Montcalieri Observatory :-

"(r) The earthquake in our region has had nearly the 